\title{
CenteringPregnancy and Health Disparities in lowa
}

\author{
Elizabeth M. Potter, $\underline{\text { CNM, WHNP, MS }}{ }^{1}$ \\ Key Words: Centering pregnancy, group prenatal care, health disparities, low birthweight, \\ preterm birth
}

\begin{abstract}
Health disparities exist among lowa's childbearing women, with preterm birth affecting Hispanic and AfricanAmerican women at disproportionate rates compared to white women. Black women are also more likely than whites or Hispanics to deliver a low-birthweight infant. CenteringPregnancy is a model of group prenatal care that may help reduce these disparities. Preliminary studies show increased birthweight, decreased incidence of preterm birth, and greater knowledge about pregnancy in Centering participants. This model should be considered for implementation and study in lowa.
\end{abstract}

${ }^{1}$ Division of General Obstetrics and Gynecology, Department of Obstetrics and Gynecology, University of lowa Health Care, lowa City, IA.

\section{Background}

An African-American woman in lowa has nearly twice the risk of delivering a low-birthweight infant (LBW, $<2500$ g) than a Caucasian woman, and is more likely to deliver preterm, before 37 completed weeks of gestation. In
2008, 12 percent of AfricanAmerican infants were LBW, compared to 6.4 percent of white infants ${ }^{1}$. From 2004-2006, 16.3 percent of black infants were born preterm, while 11.5 percent of white infants were born preterm². Hispanic/Latina women in lowa had a lower rate of LBW infants than black or white women (6.2 percent LBW), but the preterm delivery rate falls between that of black and white women, at 11.9 percent $^{2}$. As the nation debates and implements change within the healthcare system, addressing such disparities is a high priority. The U.S. Department of Health and Human Services and the Institute of Medicine have recommended development and evaluation of better prenatal interventions to address disproportionate rates of poor outcomes in disadvantaged communities ${ }^{3,4}$. In the realm of prenatal care, the model of CenteringPregnancy should be explored as an approach to decreasing disparities and improving outcomes for all lowa women.

Please cite this paper as: Potter, EM. CenteringPregnancy and Health Disparities in lowa. Proc Obstet Gynecol. 2010 Oct;1(2): Article 3 [ 4 p.]. Available from: http://ir.uiowa.edu/pog/vol1/iss2/3/. Free full text article.

Corresponding author:: Elizabeth M. Potter, Department of Obstetrics and Gynecology, University of lowa 51321 PFP, 200 Hawkins Drive, lowa City, IA 52242. Telephone, (319)356-1956. elizabeth-

potter@uiowa.edu

This is an Open Access article distributed under the terms of the Creative Commons Attribution 3.0 Unported License (http://creativecommons.org/licenses/by/3.0), which permits unrestricted use, distribution, and reproduction in any medium, provided the original work is properly cited. 


\section{Discussion}

CenteringPregnancy (Centering) is a model of prenatal care created by certified-nurse midwives (CNMs) to provide risk assessment, education, and social support within a group of 8 to 12 women with similar due dates $^{5}$. After an initial individual visit, during which a complete history and physical exam are conducted, women meet together for 10 twohour sessions at regular intervals starting between 12 and 16 weeks gestation. Sessions are led by two consistent facilitators, one clinician and a nurse, social worker, or allied health professional. Upon arrival, women take their own blood pressures and weights, and record them in their charts. During the first 15-20 minutes of a session and during a snack break while the group may socialize, women take turns with brief individual assessments by a provider who reviews recorded vital signs, measures fundal height, listens to fetal heart tones, and screens for the need for private assessment after the group. The rest of the time is spent in facilitated group discussion, with a flexible theme for each session. Topics include pregnancy discomforts, labor techniques, breastfeeding, family support, intimate partner abuse, and nutrition. The structure allows for learning from peers, increased involvement and demystification of the process of prenatal care, community-building, and more total time spent with a provider over the course of the pregnancy. The Centering model is guided by essential elements related to health promotion via group interaction, in contrast to traditional individual prenatal care (Table 1).

How does Centering affect women's knowledge, satisfaction with care, and pregnancy outcomes? Is there a role for Centering to reduce health disparities among lowa women? Existing data are promising but mixed, reflecting the small number of available studies and difficulty of evaluation of qualitative variables. Evaluation of Rising's pilot program showed client satisfaction with the model and a decrease in thirdtrimester emergency room visits compared with a conveniencechosen control group ${ }^{5}$. A prospective, matched cohort study of 458 women in urban public clinics found a statistically significant increase in birth weight among group prenatal care participants compared with those receiving individual care ${ }^{6}$. Although the study did not show a significant difference in preterm birth, the infants born preterm to mothers in group care did have significantly higher birth weights than those of mothers in individual care. Secondary analysis of a randomized, controlled trial comparing group and individual prenatal care found a significant reduction in preterm birth (33 percent risk reduction) among young, urban women involved in Centering ${ }^{7}$. Women in group care had higher rates of breastfeeding initiation, had better prenatal knowledge, and had better satisfaction with care. 
Table 1: Some essential elements of CenteringPregnancy ${ }^{1}$ compared to traditional prenatal care

\begin{tabular}{|c|c|}
\hline $\begin{array}{l}\text { Centering } \\
\text { Pregnancy }\end{array}$ & $\begin{array}{c}\text { Traditional Prenatal } \\
\text { Care }\end{array}$ \\
\hline $\begin{array}{l}\text { Health assessment } \\
\text { occurs within the } \\
\text { group space. }\end{array}$ & $\begin{array}{l}\text { Health assessment } \\
\text { occurs in private room. }\end{array}$ \\
\hline $\begin{array}{l}\text { Participants are } \\
\text { involved in self-care } \\
\text { activities. }\end{array}$ & $\begin{array}{l}\text { Vital signs, weight, and } \\
\text { urine dips are } \\
\text { performed by clinic } \\
\text { workers. }\end{array}$ \\
\hline $\begin{array}{l}\text { A facilitative } \\
\text { leadership style is } \\
\text { used. }\end{array}$ & $\begin{array}{l}\text { Clinician usually guides } \\
\text { communication and } \\
\text { interaction. }\end{array}$ \\
\hline $\begin{array}{l}\text { The group is } \\
\text { conducted in a circle. }\end{array}$ & $\begin{array}{l}\text { Clinician may be } \\
\text { standing while client is } \\
\text { seated or lying down. }\end{array}$ \\
\hline $\begin{array}{l}\text { Each session has an } \\
\text { overall plan. }\end{array}$ & $\begin{array}{l}\text { Each visit may have } \\
\text { certain goals. }\end{array}$ \\
\hline $\begin{array}{l}\text { Attention is given to } \\
\text { the core content, } \\
\text { although emphasis } \\
\text { may vary. }\end{array}$ & $\begin{array}{l}\text { Providers may vary } \\
\text { their client education } \\
\text { depending on questions } \\
\text { or needs. }\end{array}$ \\
\hline $\begin{array}{l}\text { There is stability of } \\
\text { group leadership. }\end{array}$ & $\begin{array}{l}\text { Clients may see the } \\
\text { same or different } \\
\text { providers. }\end{array}$ \\
\hline $\begin{array}{l}\text { Group conduct } \\
\text { honors the } \\
\text { contribution of each } \\
\text { member. }\end{array}$ & $\begin{array}{l}\text { Depending on } \\
\text { communication style, } \\
\text { provider or client may } \\
\text { do more talking. }\end{array}$ \\
\hline $\begin{array}{l}\text { Group size is optimal } \\
\text { to promote the } \\
\text { process. }\end{array}$ & $\begin{array}{l}\text { Usually visits occur } \\
\text { with one-to-one } \\
\text { provider/client ratio. }\end{array}$ \\
\hline $\begin{array}{l}\text { Involvement of } \\
\text { support people is } \\
\text { optional. }\end{array}$ & $\begin{array}{l}\text { Support people may or } \\
\text { may not be welcome at } \\
\text { individual visits. }\end{array}$ \\
\hline $\begin{array}{l}\text { Opportunity for } \\
\text { socializing with the } \\
\text { group is provided. }\end{array}$ & $\begin{array}{l}\text { No opportunity exists } \\
\text { for socializing with } \\
\text { other pregnant women } \\
\text { during routine visits. }\end{array}$ \\
\hline $\begin{array}{l}\text { There is ongoing } \\
\text { evaluation of } \\
\text { outcomes. }\end{array}$ & $\begin{array}{l}\text { Evaluation of outcomes } \\
\text { is done at provider and } \\
\text { practice discretion, if at } \\
\text { all. }\end{array}$ \\
\hline
\end{tabular}

${ }^{1}$ Essential elements. Centering Healthcare Institute.

http://www.centeringhealthcare.org/pages/ce ntering-model/elements.php. Updated 2009. Accessed August 18, 2010.
Baldwin ${ }^{8}$ also found that knowledge about pregnancy was greater among participants in a Centering group than those in traditional care. Robertson, Aycock, and Darnell ${ }^{9}$ conducted a quasi-experimental prospective comparison study of Centering versus traditional care for Spanish- and English-speaking Hispanic women. Their results showed no difference in infant outcomes, including birth weight and gestational age at delivery, however, the sample size was small.

Additional research is needed to incorporate greater numbers of participants, control for confounding factors, and increase research quality via randomization.

\section{Conclusion}

The literature to date shows that group care may improve rates of preterm birth and low birth weight, which are experienced at disproportionate rates by women of color in lowa. Centering may be valuable throughout the state's urban and rural communities. Existing data support outcome improvement for urban women in public clinics ${ }^{6,7}$. More research is needed on the effects of group care outside of urban settings. In rural communities, transportation may be a barrier to care, especially during periods of extreme winter weather. Group care may allow for shared transportation and easier rescheduling if clinics are closed due to storms. In areas where there are many Spanish-speaking women and a shortage of Spanishspeaking providers, group sessions 
could increase clinic efficiency. They would also allow for more time to be spent on education in communities where Spanish-language childbirth preparation classes are unavailable. Establishment of Centering in lowa would provide opportunities for research on acceptance and outcomes of this model in rural communities. Continued evaluation of the relationship between CenteringPregnancy and preterm birth would contribute to national goals set by the Institute of Medicine, which recommends research to understand the impact of the health care delivery system on preterm birth $^{4}$. CenteringPregnancy should be explored as a method of increasing access to care, improving outcomes, and decreasing perinatal health disparities in lowa.

\section{References}

1. lowa Department of Public Health Center for Health Statistics. 2008 Vital Statistics of lowa. http://www.idph.state.ia.us/apl/com mon/pdf/health statistics/2008/vital stats 2008.pdf. Accessed July 5, 2010.

2. March of Dimes. Perinatal data snapshots: lowa. http://www.marchofdimes.com/perist ats. Updated October 2009. Accessed July 5, 2010.

3. Improving Maternal Health Care: The Next Generation of Research. Conference Summary. AHRQ Publication No. 02-0025, June 2002. Agency for Healthcare Research and Quality, Rockville, MD. http://www.ahrq.gov/research/mater nhlth/

4. Behrman, R., Butler, A., Eds. Preterm birth: Causes, consequences, and prevention. Committee on Understanding Premature Birth and Assuring Health Outcomes, Board on Health Sciences Policy. Washington, D.C.: National Academies Press; 2007.

5. Rising SS. Centering pregnancy. An interdisciplinary model of empowerment. J Nurse Midwifery. 1998 Jan-Feb;43(1):46-54.

6. Ickovics JR, Kershaw TS, Westdahl C, Rising SS, Klima C, Reynolds H, Magriples U. Group prenatal care and preterm birth weight: results from a matched cohort study at public clinics. Obstet Gynecol. 2003 Nov;102(5 Pt 1):1051-7.

7. Ickovics JR, Kershaw TS, Westdahl C, Magriples U, Massey Z, Reynolds H, Rising SS. Group prenatal care and perinatal outcomes: a randomized controlled trial. Obstet Gynecol. 2007 Aug;110(2 Pt 1):330-9. Erratum in: Obstet Gynecol. 2007 Oct;110(4):937.

8. Baldwin KA. Comparison of selected outcomes of CenteringPregnancy versus traditional prenatal care. $\mathrm{J}$ Midwifery Womens Health. $2006 \mathrm{Jul}$ Aug;51(4):266-72.

9. Robertson B, Aycock DM, Darnell LA. Comparison of centering pregnancy to traditional care in Hispanic mothers. Matern Child Health J. 2009 May;13(3):407-14. 